\title{
When Violent Extremism is No Longer a Man's World: Some Evidence From Malaysia
}

Zaiton Hamin, Saslina Kamaruddin, Ahmad Ridhwan Abd Rani, Ani Munirah Mohamad and Wan Rosalili Wan Rosli

To Link this Article: http://dx.doi.org/10.6007/IJARBSS/v11-i9/11031

DOI:10.6007/IJARBSS/v11-i9/11031

Received: 08 July 2021, Revised: 24 July 2021, Accepted: 19 August 2021

Published Online: 09 September 2021

In-Text Citation: (Hamin et al., 2021)

To Cite this Article: Hamin, Z., Kamaruddin, S., Rani, A. R. A., Mohamad, A. M., \& Rosli, W. R. W. (2021). When Violent Extremism is No Longer a Man's World: Some Evidence From Malaysia. International Journal of Academic Research in Business and Social Sciences, 11(9), 479-488.

Copyright: (c) 2021 The Author(s)

Published by Human Resource Management Academic Research Society (www.hrmars.com)

This article is published under the Creative Commons Attribution (CC BY 4.0) license. Anyone may reproduce, distribute, translate and create derivative works of this article (for both commercial and non-commercial purposes), subject to full attribution to the original publication and authors. The full terms of this license may be seen

at: http://creativecommons.org/licences/by/4.0/legalcode

Vol. 11, No. 9, 2021, Pg. 479 - 488

Full Terms \& Conditions of access and use can be found at http://hrmars.com/index.php/pages/detail/publication-ethics 


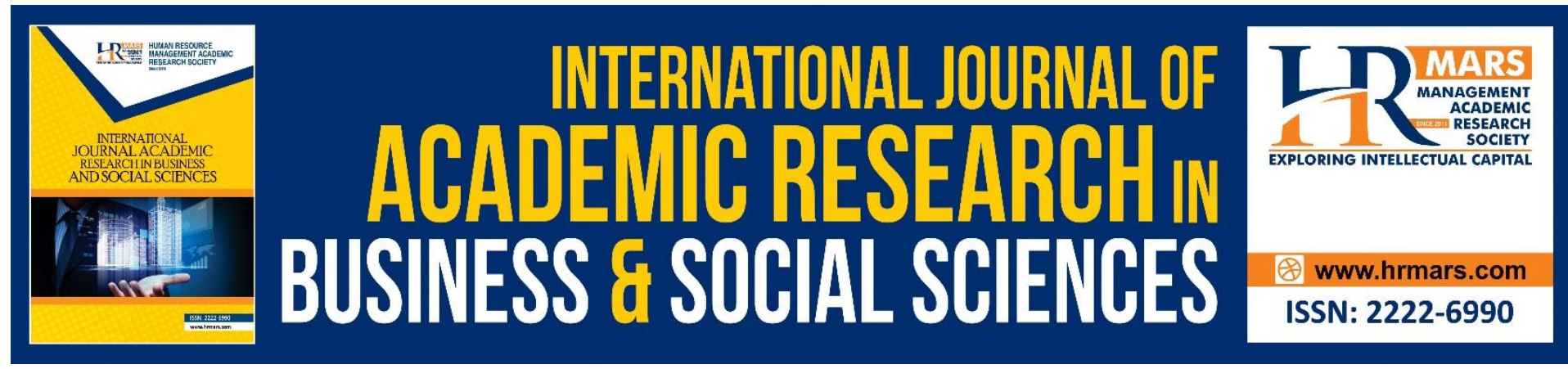

\title{
When Violent Extremism is No Longer a Man's World: Some Evidence From Malaysia
}

\section{Zaiton Hamin ${ }^{1}$, Saslina Kamaruddin², Ahmad Ridhwan Abd Rani $^{3}$, Ani Munirah Mohamad ${ }^{4}$ and Wan Rosalili Wan Rosli ${ }^{5}$}

${ }^{1}$ Faculty of Law, UiTM Shah Alam, Selangor, Malaysia, ${ }^{2}$ Faculty of Management \& Economics, Sultan Idris Education Universit, Perak, Malaysia, ${ }^{3,5}$ Faculty of Law, UiTM Shah Alam, Selangor, Malaysia, ${ }^{4}$ College of Law, Government \& International Studies (COLGIS)

UUM, Sintok, Kedah Darul Aman, Malaysia

Email: zaiton303@uitm.edu.my

\begin{abstract}
Traditionally, terrorism and violent extremism (VE) are synonymous with male perpetrators, although women are inevitably and adversely affected by such illegalities. Women are increasingly involved as active supporters not only by fundraising terrorist activities but also as lone wolf suicide bombers. Despite the awareness of women's participation, and the detrimental impact of such crimes on women, the lack of understanding of the causes of Malaysian women's radicalisation and their political agency has remained under-researched. The understanding of such rationales and agency is crucial to enable the government to adopt the appropriate PVE/CVE approach. Given the lack of academic research on this issue, this paper aims at examining the understanding of VE, the role and the causal factors of women's radicalisation and their implications on the visibility of women's agency and gender equality in Malaysia. This research employs qualitative methodology, in which the primary data was collected through semi-structured interviews with fifteen respondents. The data triangulation was obtained from focus group discussions with experts from relevant ministries and universities. The data is analysed and interpreted using Atlas.Ti software. The findings revealed that the drivers toward women's radicalisation are varied, and the lack of visibility of women's political agency in the analyses of Malaysian women's participation in VE is unfortunate. Such a situation calls into question not only the future role of women as active actors in PVE/CVE but also the promotion of gender equality as envisaged by the UN Security Council Resolutions 2178 and 2242 and SDG No 5 and 16.
\end{abstract}

Keywords: Violent Extremism, Terrorism, Women, Push and Pull Factors, Radicalisation, Agency, Gender Equality

\section{Introduction}

Violent extremism (VE) in Malaysia has a long history, which dates back to the Malayan Emergency period in 1948-1960. The government had to counter new extremist elements or communist insurgency during those challenging anti-colonial and post-independence era (elMuhammady, 2016). The success of that approach informs the current strategies in 
countering radical Islamist tendencies and recruitment of extremist groups such as $\mathrm{Al}$ Maunah, Kumpulan Mujahidin Malaysia (KMM), Jemaah Islamiah (JI) terrorists, Al-Qaeda linked terrorists and Islamic State (IS) (el-Muhammady, 2016). The recent Global Terrorism Index 2016 published by the Institute of Economics and Peace ranked Malaysia at number 61, which is an increase from number 90 in 2012 of the countries facing the impacts of terrorism (Malik \& Kepli, 2018).

In recent time, violent extremism has begun to proliferate following the September 11 attacks in 2001 and has now become entrenched in domestic and international discourse and practice as the principal 'root' of terrorism. VE is a multi-dimensional and complex phenomenon which does not appear to possess any single agreed definition as it is defined differently by different commentators and is often used interchangeably with terrorism. Ali and Husin (2017) argues that the definition of extremism is a preamble to terrorism. Despite the lack of definite meanings, VE suggests the willingness to use violence, or to support the use of violence, to further particular beliefs of a political, social, economic or ideological nature (European Parliament, 2017).

Within the global context, commentators argue that terrorism and violent extremism are highly gendered activities, leaning toward male perpetrators (Couture, 2014; Ali and Husin, 2017). Women's participation in a supportive role has been documented (Asante \& Shepherd, 2020; Grossman, Carland, Tahiri, Zammit, 2018) and of late, such role has shifted to more combative and aggressive roles than before. The literature indicates that understanding the workings and impact of gender dynamics in perpetuating gender inequalities and encroaching on fundamental human rights are pertinent to guiding official and civil society responses to these challenges (Couture, 2014).

Within the local setting, the literature on the causal factors of women's engagement in VE, let alone on PVE/CVE strategies affecting women in Malaysia is relatively scarce. Recent literature is mainly concerned with the nature and origin of the threats of terrorist groups and ISIS/Daesh and the countermeasures taken the Malaysian authorities (elMuhammady, 2016), the role of played by women in Daesh (Shahruddin \& Mohamad, 2020) and legislative responses toward such criminality (Hamin \& Kamaruddin, 2019). Despite the increasingly active role that women play in such crimes, the rationale for their radicalisation has remained under-researched in Malaysia. It is within this context that this paper aims at examining the role of women involved in VE and the push and pull factors contributing to such involvement and their implications for gender equality in Malaysia. As such, this paper intends to fill in the gap in the literature on the Malaysian women participation in VE.

The first part of this paper examines the legal responses to radicalisation that appears to be in a similar vein to terrorism. The second part explains the methodology adopted by the researchers in conducting the research. The third part, which is the crux of the study, explains the findings on the perception of VE, the changing role of women in VE and the contributing factors for such illegality and its impact on the women's agency and gender equality in Malaysia. The discussion in the fourth section discusses the relationship between the findings and the literature before the last section concludes the paper.

\section{The Legal Responses to Violent Extremism and Terrorism}

In dealing with the challenges of radicalisation and terrorism threats within the country, Malaysia has created two relevant legislation, namely the Prevention of Terrorism Act 2015 (POTA) and the Special Measures Against Terrorism in Foreign Countries Act 2015 (SMATA). Both legislations are consistent with the spirit and purpose of UNSCR 2178, particularly in 
monitoring the activities and threats of foreign terrorist fighters (Hamidi, 2016). Prior to these legislations, there was the Internal Security Act 1960 (ISA), which contained numerous executive actions against radical behaviours (Hamidi, 2016). The ISA was very unpopular and was finally replaced by the Security Offences (Special Measures) Act (SOSMA) 2012, which is a security-related law (Abdullah \& Rahim, 2012).

The POTA 2015, which was created under Article 149 of the Malaysian Federal Constitution (Zubair et al., 2015) enables the Malaysian authorities to detain terror suspects without trial for two years, and it does not allow any judicial review on the detention (Section 13(1)(b)). However, the detention will be reviewed by the Prevention of Terrorism Board, which is appointed by the King (Section 19(1)). SOSMA is a preventive law which was created to protect the lives and property of the citizens. The Act provides special measures in dealing with security offences and recognises the grave risks to internal security and public order presented by the threat of terrorism, sabotage, and espionage (Dhanpal and Sabaruddin, 2017). The Penal Code was also recently amended in 2007 to include offences relating to terrorism under Chapter VIA. The new offences include committing terrorist acts (Section 130C), providing devices to terrorist groups (section 130D), recruiting members of terrorist groups or participating in terrorist acts (Section 130E) and providing training and instruction to terrorist groups and persons committing terrorist acts (Section 130F).

In light of the creation of the new anti-terrorism law in the Penal Code, the Criminal Procedure Code was also amended to provide for a wide range of investigatory powers to the police and the Public Prosecutor, including the power to intercept communications. Sections 106A and 106C allowed the police used to intercept, detain and open postal articles and messages transmitted via telecommunications where all intercepted communications can be used as evidence for trial in terrorism (Zubair et al., 2015). These powers may be invoked on a low standard of proof and without sufficient human rights, content-based safeguards (Malaysian Bar Council, 2010). The critique of such powers is that when based on these unchecked definitions, investigations into alleged terrorist activities which are defined broadly would be carte blanche for numerous civil liberty infringements (Malaysian Bar Council, 2010).

\section{Methodology}

This research adopts qualitative methodology, which provides a deeper understanding of VE as an emerging social phenomenon and a comprehensive overview of such illegality (Silverman, 2013). The findings are based on the data collection of both the primary and secondary data, and the stage is divided into two phases. The first stage is the literature review stage (Bell, 1987) in which the relevant literature on VE, the concepts and motivations and the laws governing such crimes were analysed. The primary sources include all the relevant anti-terrorism laws, including the Penal Code, the Prevention of Crime Act (POCA) 1985 and the Prevention of Terrorism Act (POTA) 2015. The secondary sources include textbooks, journal articles, government reports, newspaper articles and online sources.

The second phase of the data collection is the fieldwork, in which the primary data was generated from face-to-face semi-structured interviews with fifteen respondents, including prosecutors from the Attorney General Chambers; officers from the Royal Malaysian Police, anti-terrorism agencies, a regulatory body, a representative of the Bar Council, legal practitioners, women's non-profit organisations (NGOs) and parents of foreign fighters. The focus group discussions with experts from the Ministry of Home Affairs and law academicians from four law universities respectively triangulated the primary data. The interview method 
was chosen as it provided the researchers with the opportunity to explore the respondents' opinions of VE and women in-depth, rather than to test their knowledge or only to categorise it (Crouch and McKenzie, 2006). The sampling method was purposive sampling, where the respondents were selected because they were likely to generate useful data for the research (Crouch and McKenzie, 2006).

The said interviews and discussions were digitally recorded, and their contents were later transcribed and analysed using the Atlas.Ti qualitative research software (Friese, 2014).The qualitative data analysis was conducted through thematic and content analysis, in which the observations and the interview transcripts from the semi-structured interviews and discussions were examined (Seidman, 2006). The process consisted of creating codes and categories, considering the themes and then analysing the respondents' perceptions and experiences, along with the literature review. The results obtained from the primary and secondary data led to the findings, which will be discussed below.

\section{Findings}

\section{Understanding of Violent Extremism}

The findings revealed that most respondents' understanding of violent extremism suggests that VE is a contested concept. Several respondents believed that VE involves some kind of radical beliefs towards a specific cause and the believers are willing to die for such causes. $A$ respondent from a regulatory body stated that:

I think violent extremism is a radical belief towards a cause (for example, religion, race, nation and deviant teaching) and they need to use force to attain that cause. They are not afraid to die for their causes. They think whatever destruction they caused is just collateral damage.

Most respondents believed that VE would usually be linked to Jihad and religious-based terrorism. A respondent from the counter-terrorism agency noted that:

In Europe, VE is a vast concept, including left-wing or right-wing political extremists. But in Malaysia, VE is usually linked to Jihad and religious-based terrorism or Islamic terrorism, such as Jemaah Islamiyah (JI) or Daesh terrorist group.

\section{Stereotyping Women as Victims of VE}

The findings revealed that most respondents saw stereotyped or instrumentalist women as passive and helpless victims of VE. A respondent observed that:

Women generally don't go out looking to join VE groups like men. They got involved in VE through marriage and sometimes they might be forced to join violent groups or abused in some ways in conflict and post-conflict zones.

Another respondent from an NGO stated that:

I think, when compared to men, women and children all over the world are mainly the victims of terrorism or violence. For example, in the Rohingya crisis, they are the people who are most affected by such war crimes. 


\section{Shifting Role from Supporters to Lone Wolf Suicide Bombers}

The findings indicated that some of the respondents were concerned about the changing role of women from being mere passive supporters to field operatives, including suicide bombers. A respondent from law enforcement observed that:

It is surprising to learn from anti-terrorism arrest in our country that a housewife had turned into a mastermind to run down non-Muslim voters during the Election Day and was also planning to destroy a temple in $\mathrm{KL}$ using her car with a gas canister to cause an explosion. She's on a suicide mission.

\section{Rationales for Women's Radicalisation}

Identity Differentiation or 'Us-versus-Them' Mentality

The findings indicated that similar to male radicalisation, the early warning indicators for female extremists were the 'us-versus-them' sentiment combined with the belief that violence was the legitimate means to an end. A respondent indicated that:

These people might feel that since they preferred a full Islamic state in Malaysia, they were being discriminated against by the government, which led them to accept the Daesh ideology, similar to those people in Iraq and Syria. So they prefer to belong to that brotherhood or sisterhood group (Ukhuwwah) and think that violence is the only way forward.

Another respondent observed that:

The Daesh/ISIS group has established a support system to new members, which provides a sense of belonging and brotherhood or sisterhood to these likeminded individuals. If you don't subscribe to Daesh ideology and their VE cause, you are not one of them and are not welcomed.

\section{Religion}

The findings revealed that despite many causal or pull factors, women seemed to be more attracted to religious factors. Most respondents perceived that religion was the catalyst in radicalisation of individuals, including Malaysian women, to join Daesh. A respondent opined that:

VE groups like Daesh have the Alkhansaa Bridget, which encourages women to go to Syria to fight in the name of religion or Jihad. Usually, if the women are single, they would be encouraged to marry a freedom fighter there.

\section{Deviant Islamic Teachings}

The findings showed that deviant teachings were responsible for Malaysians, including women, to travel to Syria to fight for Daesh and to perform Jihad. A respondent who has been involved in the rehabilitation of former Jihadist foreign fighters explained that:

When we talked to those people who have been involved in Jihadist or radical movement and have fought in wars abroad, we found that most of them were influenced by the misinterpretation of the Al-Quran or deviant teachings of Islam that the only way to achieve absolute martyrdom and go to Heaven is by joining Jihadist groups such as AlQaeda or Daesh and fight against the infidels. This is not what Islam is preaching. 


\section{Use of the Internet and Social Media}

The findings suggested that most respondents believed that the increasing use of ICT, particularly the social media platform, was responsible for radicalising women in the country. A respondent stated that:

There are many reasons why some people and women especially, want to join Daesh or become Daesh brides. They may have been connected and recruited into such groups via email or social media platforms.

\section{Political Differences}

The findings revealed that some respondents believed that the political differences the individuals or women have with authority as a reason to engage in VE. A respondent stated that:

The failure of the Malaysian government to implement Islamic law is an excuse for the extremist group for not recognising the government and their leaders. They believed that the government should follow the Al-Tawheed Hakimiyyah duty to implement full Islamic law in the country.

\section{Indoctrination via VE Propaganda}

The findings indicated that majority of the respondents thought that the level and the frequency of indoctrination to radical materials and propaganda via online and religious classes or usrah would most likely influence an individual, including women, to join that extremist group. A respondent stated that:

These people or women who joined Daesh/ISIS can be indoctrinated by daily exposures to pro-violence or pro-ISIS materials online and by attending religious classes or what they call usrah.

\section{Tyranny against Islam and Muslims}

The findings suggested that some respondents believed that individuals, particularly Malaysian women, maybe radicalised into supporting Daesh/ISIS due to their beliefs of tyranny against Islam and Muslims in many parts of the world. A respondent commented that:

The atrocity against Sunnis in Syria and the Israeli regime's oppression against the Palestinians in Gaza have encouraged Malaysian men and women to join the Daesh group, which they see as defending those oppressed Muslims.

\section{Following Spouse and Family Obligations}

The findings showed that most respondents perceived that some women who joined the Daesh group or became supporters or recruiters for Daesh/ISIS might not have any radical ideas but were mainly following their spouses and love for their spouses or family members who had become members of such groups. A respondent from the Royal Malaysian Police observed that:

Most of the time, when women join Daesh or any Islamic-based radical or terrorist group, usually they don't have any grand ideological views about toppling any government. They were mainly following their husbands to go to Syria with their kids, and they don't want to be separated as a family. 


\section{Discussion}

The narratives of the respondents on their understanding of VE appears to be in line with the literature that such illegality is closely connected to terrorism-related offences and are mainly ideologically and politically motivated (Kirkpatrick, 2019; Dong, 2019). The findings also support previous studies which showed that the lure of joining an extremist group such as Daesh or participating in VE involves a complex interplay of pull and push factors on the individual level (elMuhammady, 2016; Evans, Milton, \& Young, 2020).

The tyranny against Islam and Muslims is an external factor which implies cognitive radicalisation, and is based on the belief and attitude in a sacred cause or religious duty (fardhu ain) and that the perpetrator's Islamic community was victimised by another (Muna, 2020; Ahmad elMuhammady, 2016). Such a finding supports current literature, implying that when combined with other push factors such as discussions in religious classes, and susceptibility to manipulation by extremist propaganda, VE remained a distinct possibility (elMuhammady, 2016; Macnair, 2020).

The findings on following spouse or family obligations suggest that there is a distinction between cognitive and behavioural radicalisation, the latter is merely focusing on extremist behaviour or action. Such a dichotomy seems to confirm the literature on radicalisation (Ryan, 2019; Dzhekova et al., 2017) and contemporary theories of radicalisation such as the two-pyramid approach of Zeiger, Alonso \& Herrera, (2019). Moreover, the fact that the love for their spouses or family members who were fighting in Syria or Iraq as the reason for joining Daesh and travelling to those countries may fit into any of the elements of McCauley and Moskalenko's Friction, four individual-level mechanisms (Love, Risk and Status, Slippery Slope, Unfreezing).

The findings on the shift in the role of women in VE from passive, helpless victims to active player confirm the current literature on radicalisation (Braddock, 2020; Stinton, 2019; Baugut, \& Neumann, 2019; McCauley \& Moskalenko, 2017). The evidence of the existence of a lone wolf attacker suggests that such a changing role may challenge the stereotypical notion of women as merely victims of VE. However, for the disconnected-disordered type of lone wolf radicals, they may move to violence not only from radical ideas of grievance but from elements of unfreezing, escape, and status-seeking (Hartleb, 2020; McCauley \& Moskalenko, 2014).

It is noteworthy that the invincibility of women's political agency seems to surface in the narratives or characterisation of women travelling to Iraq and Syria to join Daesh, which seem to emphasise the notion that these women have limited agency in their choice to travel, and they are either being forced or coerced by spouse or men to join ISIS. Besides, similar lack of women agency is perpetuated by the stereotypical view of women as passive victims of such extremism, despite recent cases of the varied role women play in violent extremism (Auchter, 2020; Hamin \& Kamaruddin, 2020).

\section{Conclusion}

It is interesting to note that the findings seem to exclude socio-economic factors such as poverty from the causal equation of $\mathrm{VE}$, implying that poverty is not a useful explanation of women's radicalisation in Malaysia. Such findings confirm Crenshaw's assertion (1981) that many extremists and terrorists, perhaps most of 1970s terrorists who grew out of student unrest, came from middle-class and professional families. It also supports Ramakrishna's views (2005) that in Malaysia, socio-economic factors are not considered as the causative elements of terrorism. However, Ramakrishna also contends that in a Muslim majority 
country such as Malaysia, such factors might be used in recruiting followers and generate 'political oxygen' exploited by extremists to create an ideological "Grand Narrative" of American's subjugation of Islam and that it was their religious obligation to wage Jihad to defend Islam.

The findings revealed that the push and pull factors in women's radicalisation are diverse from political reasons to religious to personal to supportive ones or what is termed as 'sympathetic radicalisation' (elMuhammady, 2016), arising from the identity differentiation mentality of the Malaysian women in question. Despite such varied rationales, the lack of the visibility of women's political agency in the findings is glaring, suggesting that women's perspectives of empowerment and responsibility for their choices or actions are not expressly acknowledged. The recognition of such an agency would enable a better understanding of the process and rationales by which women came to be involved initially in VE. It is contended that the lack of women's agency does not augur well for women's role in PVE/CVE and calls into question the development of a gendered approach in PVE and CVE strategies, which might inevitably inhibit gender equality in Malaysia as envisaged by the UN Security Council Resolutions 2178 and 2242 and SDG No 5.

\section{Acknowledgements}

This work was supported by research grant FRGS/1/2019/SSI10/UITM/02/2 by the Research Management Centre, UiTM Shah Alam, Selangor.

\section{References}

Asante, D., \& Shepherd, L. J. (2020). Gender and Countering Violent Extremism in Women, Peace and Security National Action Plans. European Journal of Politics and Gender.

Auchter, J. (2020). The personal is political: Feminist critiques of countering violent extremism. In Encountering extremism. Manchester University Press.

Baugut, P., \& Neumann, K. (2019). Online propaganda use during Islamist Radicalization. Information, Communication \& Society, 1-23.

Braddock, K. (2020). Weaponized Words: The Strategic Role of Persuasion in Violent Radicalization and Counter-Radicalization. Cambridge University Press.

Couture, K. L. (2014). A Gendered Approach to Countering Violent Extremism: Lessons Learned from Women in Peacebuilding and Conflict Prevention Applied Successfully in Bangladesh and Morocco. Centre for 21st Century Security and Intelligence at Brookings.

Crouch, M., McKenzie, H. (2006). The Logic of Small Samples in Interview-based Qualitative Research. Social Science Information. Vol. 45 No. 4 pp: 483-499.

El-Muhammady, A. (2016). Countering the Threats of Daesh in Malaysia. Countering Daesh Extremism: European and Asian Responses, 105-122.

Evans, T., Milton, D. J., \& Young, J. K. (2020). Choosing to Fight, Choosing to Die: Examining How ISIS Foreign Fighters Select Their Operational Roles. International Studies Review.

Grossman, M., Carland, S., Tahir, H., Zammit, A. (2018). The Roles of Women in Supporting and Opposing Violent Extremism: Understanding Gender and Terrorism in Contemporary Australia, Deakin University.

Hamin, Z., Kamaruddin, S. (2019). When Women are the Criminals: Governing Violent Extremism in Malaysia via 'Hard' and 'Soft' Modalities, Global J. Bus. Soc. Sci. Review, 7(1), 48-53.

Hartleb, F. (2020). Counter-Strategies and Prevention in Lone Wolves (pp. 149-171). Springer, Cham. 
Kirkpatrick, D. (2019). Political Expression and Conflict Transformation in Divided Societies: Criminalising Politics and Politicising Crime. Routledge.

Macnair, L. (2020). From Empty to Angry: Extremism, Modernity, and the Search for Identity (Doctoral dissertation, Arts \& Social Sciences: School of Criminology).

Muna, W. (2020). Family-Based Networks: Soft Policy Tools in Countering Radicalisation to Violent Extremism in Terrorism and Developing Countries. IntechOpen.

Rosli, W. W. R., Kamaruddin, S., Hamin, Z. (2020). Legal Intervention in Combating Terrorism and Violent Extremism in Malaysia, International Journal of Innovation, Creativity \& Change, 104-114.

Ryan, S. X. (2019). An Investigation of Resilience Constructs Alongside the Role of the Community, Religiosity and Attitudes of Intolerance: Implications for Countering Extremism (Doctoral dissertation, University of Huddersfield).

Seidman, I. (2006). Interviewing as Qualitative Research. New York: Teachers College Press.

Silverman, D. (2013). Doing Qualitative Research. Los Angeles: SAGE.

Stinton, C. (2019). Combining the Aberrant with the Ordinary: The Role of White Supremacy in the Far-right Radicalisation of Women. Journal of Applied Psychology and Social Science, 5(1), 86-115. 